POLITICS AND INTERNATIONAL RELATIONS

\title{
The Electoral Buzz: Rational Prospective Voting and the Politics of the Zika Epidemic in Brazil
}

\author{
Kelly Senters Piazza ${ }^{1}$ and Rodrigo Schneider ${ }^{2}$ \\ 1 United States Air Force Academy, US \\ 2 Skidmore College, US \\ Corresponding author: Kelly Senters Piazza (kelly.piazza@usafa.edu)
}

This article reevaluates often-made assumptions of retrospective voting and voter irrationality in studies of voting behavior in political contexts colored by haphazard, apolitical events. To do so, it leverages the quasi-random 2015-2016 Zika epidemic in Brazil and the accompanying priming of "women's issues" relating to infant health to empirically assess whether exposure to the virus increased political support for female candidates in the 2016 Brazilian local elections. Results of difference-in-difference analyses suggest that high incidences of the virus in the months immediately preceding the election increased female candidates' vote shares. Conflicting with theories of irrational retrospective voting, the results are consistent with an understudied theory of rational prospective voting. Robustness and falsification tests and dubious support for alternative explanations lend additional support to the argument. The research contributes to an elucidation of both the complex calculations underlying voting behavior and the conditions favorable to female candidates' electoral prospects.

Esse artigo reavalia o tema do voto retrospetivo e do voto considerado irracional, ou seja, aquele em que eleitores punem incumbentes por eventos que estão fora do seu alcance. Para tanto, analisamos a epidemia do Zika vírus no Brasil entre 2015 e 2016, cuja proliferação e concentração geográfica pode ser considerada aleatória e cujo efeitos danosos estão relacionados à saúde do feto de gestantes, e testamos se lugares com maior prevalência do vírus deram maior suporte eleitoral para mulheres que se candidataram ao cargo de prefeita nas eleições municipais de 2016. Usando o método econométrico de diferença em diferenças, achamos o resultado de que o voto para candidatas aumentou relativamente mais entre 2012 e 2016 em áreas mais afetadas pelo vírus. Esse resultado é consistente com o fato de que prefeitas provém resultados mais bem sucedidos na área de gestação do que prefeitos. Nosso artigo, portanto, mostra evidência contrária ao voto retrospetivo e irracional e se alia mais à hipótese de que eleitores votam de maneira prospectiva e em função de expectativas racionais de desempenho futuro. Nossos testes de robustez e considerações de hipóteses alternativas reinforçam essa última hipótese. Encerramos o nosso artigo com uma discussão de como nossos resultados podem ajudar pesquisadores no entendimento de comportamento eleitoral e das condições mais favoráveis ao sucesso eleitoral de mulheres que optam por carreiras políticas.

Prominent scholars of political behavior concede that retrospective, accountability-based voting informs electoral decisions (Downs 1957; Key 1966; Fiorina 1981; Anderson 2007; Healy and Malhotra 2013). However, recent studies of the electoral effects of indiscriminate events relating to the weather (Gasper and Reeves 2011; Sinclair, Hall, and Alvarez 2011; Cole, Healy, and Werker 2012; Fuchs and RodriguezChamussy 2014; Fair et al. 2017), shark attacks (Achen and Bartels 2004a), and sporting events (Healy, Malhotra, and Mo 2010; Miller 2013) have called into question the assumption of rationality often presumed to accompany retrospective voting. Collectively, the findings of these studies suggest that, beyond rewarding or punishing incumbent politicians for outcomes or performance within their control (in accordance with conventional retrospective voting theories), voters sanction politicians for haphazard, apolitical events with adverse public consequences. Is this practice universal? Under certain circumstances, 
do voters leverage alternative electoral mechanisms? As Sinclair, Hall, and Alvarez (2011) suggest, we know little about alternative implications of electoral behavior in the face of haphazard, apolitical events.

This article evaluates the operation of a competing rational prospective theory of voting through a study of the politics of the Zika virus in Brazil. Specifically, we consider whether the coincidence of Brazil's 20152016 Zika epidemic and the unanticipated emergence of pressing challenges to infant health-an issue often perceived to be a "women's issue"-influenced voting behavior in ways other than through the incumbent vote share. More pointedly, we consider whether exposure to the Zika virus affected voters' political support for female mayoral candidates in local Brazilian elections. Through studying the politics of the Zika virus, we shed light not only on the utility of rational prospective voting but also on the ill-understood circumstances that motivate Latin Americans to apply gender stereotypes in their assessments of political leaders (Setzler 2019).

The first case of the mosquito-borne Zika virus in Brazil was documented in May of 2015. By November of that year, the number of reported cases of the virus burgeoned, and the Brazilian government declared a national emergency. The Zika outbreak continued unabated in the following year, during which period 170,535 cases of Zika were reported (BBC 2017). It was not until the spring of 2017 that the national emergency terminated.

The Zika epidemic was especially alarming to both the Brazilian government and the public alike due to its strong link to microcephaly, a birth defect characterized by abnormalities in the size of infants' heads. The Zika virus and accompanying crisis in infant health primed issues that female politicians are perceived to be especially adept at addressing in the months leading up to the 2016 local elections in Brazil (Alexander and Andersen 1993; Huddy and Terkildsen 1993). We leverage the quasi-random experiment afforded by the indiscriminate outbreak of the 2015-2016 Zika epidemic to estimate the effect of the virus (resulting in a primed "women's issue") on political support for female candidates in the 2016 Brazilian local elections.

Our primary analysis is a difference-in-difference analysis that compares female mayoral candidates' vote shares in the 2012 and 2016 Brazilian municipal elections across municipalities with varying levels of exposure to the Zika virus. We find that municipalities with more exposure to the Zika virus witnessed a statistically significantly greater increase in the female vote share from 2012 to 2016 than municipalities with less exposure to the Zika virus. Specifically, we learn that if the number of cases of Zika per 100,000 residents increases by 10 percent in the two months prior to the 2016 mayoral election, then the vote share for female mayoral candidates is predicted to increase by 0.579 percent. The effect is larger if we restrict our sample to consider solely cases of Zika among pregnant women. Although the magnitude of our results is small and unlikely to change electoral outcomes, in light of the impeachment of Brazil's first female president and the anti-women backlash surrounding her removal from office (Romero and Kaiser 2016), that we observe any effect of exposure to the Zika virus is indicative of the electoral salience of the priming of "women's issues" in advance of electoral contests.

\section{Where Politics and Gender Collide: A Review Retrospective voting and beyond}

Scholars have long sought to understand the many factors that influence voting behavior and, through their research findings, have largely conceded that theories of retrospective voting explain voting behavior in a multitude of contexts (Downs 1957; Key 1966; Fiorina 1981; Anderson 2007; Healy and Malhotra 2013). ${ }^{1}$ Theories of retrospective voting posit that voters' electoral decisions are informed by their evaluations of incumbent performance. Specifically, positive evaluations of incumbent performance lead voters to reward incumbent politicians or parties, and negative evaluations of incumbent performance lead voters to punish incumbent politicians or parties. Numerous studies provide compelling evidence in support of this theory of retrospective voting, especially in subsets of the literature assessing economic voting.

Newer scholarship extends conventional research on retrospective voting to consider its leverage in explaining voting behavior in the aftermath of indiscriminate, apolitical events relating to the weather (e.g., Gasper and Reeves 2011; Sinclair, Hall, and Alvarez 2011; Cole, Healy, and Werker 2012; Fuchs and RodriguezChamussy 2014; Fair et al. 2017), shark attacks (Achen and Bartels 2004a), and sporting events (Healy, Malhotra, and Mo 2010; Miller 2013). As previously documented, many of these studies largely confirm the continued operation of retrospective voting in the form of voters punishing incumbent politicians for the

\footnotetext{
1 See Anderson's (2007) and Healy and Malhotra's (2013) annual reviews for comprehensive reviews of this literature.
} 
uncontrollable, adverse effects of floods, animal attacks, and painful athletic defeats. Such observations have led many to deduce that voters fail to exhibit rational behavior at the polls.

This article studies an epidemic comparable in nature to events traditionally studied in this part of the retrospective voting literature with the intention of probing the often-made assumption of voter irrationality. Specifically, it reevaluates the literature-informed expectation that voters behave irrationally as a consequence of haphazard frustration with apolitical calamities. It considers whether, under certain circumstances, voters practice restraint in sanctioning elected officials for circumstances beyond their control. This articles asks whether such indiscriminate events can, instead of activating retrospective voting and indiscriminate sanctioning of the incumbent, induce voters to practice rational prospective voting.

Rational prospective voting, contrary to retrospective voting, affirms that voters make levelheaded electoral decisions on the basis of how they anticipate a candidate or party to perform in the future. We assess whether, in the face of hardship stemming from a quasi-random epidemic, voters renounce haphazard, retrospective punishment of incumbents in favor of making rational decisions arrived at through the sensible activation of prospective voting. The literature-informed, gendered nature of the adverse effects to infant health stemming from the Zika epidemic in Brazil demands that we assess the activation of prospective voting informed by heuristics on gender stereotypes. In what follows, we provide a brief overview of the knowledge accumulated on political gender stereotypes in an effort to justify our focus on this particular heuristic.

\section{Gender stereotypes: Perceptions and realities}

In recent decades, a sizable literature on gender stereotypes relating to politics-chiefly in the context of the developed world-has emerged. Gender stereotypes relating to politics primarily concern personality traits, ideological affinities, and issue competencies. With respect to personality traits, female politicians are perceived to be more empathetic, compassionate, helpful, and consensus building and less corrupt than their male counterparts (Alexander and Andersen 1993; Huddy and Terkildsen 1993; Morgan 2015; Funk, Hinojosa, and Piscopo 2019). Female politicians, in comparison with their male counterparts, are also more likely to be thought of as political outsiders (Funk, Hinojosa, and Piscopo 2019). Male politicians, by contrast, are considered more assertive, dominant, and ambitious (Eagly and Karau 2002; Dolan 2010; Bauer 2015).

In terms of ideological affinities, female politicians are considered more liberal than male politicians (Huddy and Terkildsen 1993; McDermott 1997; Herrnson, Lay, and Stokes 2003; Lloren, Rosset, and Wüest 2015). Although much of the empirical support underlying this connection stems from studies of developed countries, Escobar-Lemmon and Taylor-Robinson (2009) and Morgan and Buice (2013) identify an intricate relationship between the Latin American Left and women's movements, feminist policies, and support for female political leaders. Their scholarship serves, in part, to corroborate the overarching stereotype derived from observations of the developed world.

Finally, regarding issue competencies, male politicians, are perceived as especially proficient policy makers in the areas of the economy, agriculture, employment, fiscal affairs, crime, and security (Lawless 2004; Herrnson, Lay, and Stokes 2003). Female politicians, by contrast, are generally perceived as especially adept policy makers in education, health, and other issues relating to "children and family" (Leeper 1991; Alexander and Anderson 1993; Huddy and Terkildsen 1993; Herrnson, Lay, and Stokes 2003). The scholarly literature finds the connection between female representatives and issue spaces pertaining to education, health, and "children and family" to be universal. Research conducted on the Latin American region substantiates this claim.

According to Morgan (2015), in Latin America, the interconnectedness of female politicians and family emphasis is especially pronounced. In her seminal book, Chaney $(1979,21)$ argues that female politicians in the region view themselves as "supermadre[s], tending the needs of [their] bigger family in the larger casa of the municipality or even the nation." Schwindt-Bayer (2006) finds that although female legislators' perceptions of their roles as politicians have evolved since the time of Chaney's (1979) writing, female legislators continue to place higher priority on "women's issues" and children and family concerns than do their male legislative counterparts.

Gender stereotypes in each of the aforementioned areas may be formed on the basis of or reinforced by cross-gender disparities in legislation, bill introduction, or general behavior in campaigns and in the legislature (Herrnson, Lay, and Stokes 2003; Chattopadhyay and Duflo 2004; Franceschet and Piscopo 2008; 
Schwindt-Bayer 2010; Lloren, Rosset, and Wüest 2015; Hinojosa et al. 2018). ${ }^{2}$ In the Latin American context, specifically, Franceschet and Piscopo (2008) find that women are gendering the legislative agenda, and Schwindt-Bayer (2010) claims that women provide substantive representation to other women as a function of their emphasis on women's issues.

Especially pertinent to our research is Brollo and Troiano's (2016) finding that, in Brazil, the election of female mayors results in better congenital health outcomes for women than the election of male mayors. In an effort to learn about the effects of the gender of elected officials, Brollo and Troiano (2016) exploit a quasiexperiment afforded by close election results to overcome endogeneity challenges relating to gender. They find that when female candidates win local elections, there is an increase in the share of pregnant women attending at least one prenatal care visit and a decrease in the share of women giving birth prematurely. Brollo and Troiano (2016) both demonstrate the utility of quasi-experimental research designs in uncovering unprecedented insights on gender politics and provide a compelling reason for voters to logically anticipate an intimate connection between the gender of elected officials and issues prioritized in office.

Despite the accumulation of literature attempting to identify perceived gender personality traits, ideological affinities, and issue competencies and to compare attitudinal and behavioral differences across male and female lawmakers, less is known about whether and the conditions under which gender stereotypes inform voters' political behaviors and electoral choices (Lawless 2004; Dolan 2010, 2014; Hayes 2011; Morgan and Buice 2013; Bauer 2015; Setzler 2019). Some scholars have attempted to fill this void with studies assessing the conditions under which political parties or voters activate gender stereotypes relating to personality characteristics. Funk, Hinojosa, and Piscopo $(2019,2017)$ find that political parties are more likely to nominate women as public political trust in institutions falls because women are considered both political outsiders and less corrupt and more honest than men are. However, it is unclear whether similar behaviors emerge in political contexts afflicted by unforeseen natural disasters and epidemics. The standard belief is that female candidates are more successful when they capitalize on "gender issue ownership," meaning that they run "as women" and emphasize "women's issues" (Herrnson, Lay, and Stokes 2003). Whether this belief holds in light of unforeseen natural disasters and epidemics (and if it does, whether it resonates with voters and shapes electoral decisions) remains unknown.

\section{From Zika to Electoral Support for Women: A Sequential Logic}

Our research assesses whether exposure to the plausibly indiscriminate Zika virus encourages rational prospective voting, activates the use of gender stereotype-based heuristics, and results in increased electoral support for female candidates. In an effort to assess these relationships, we investigate the sequential logic and mechanism as outlined here:

Electoral season exposure to Zika $\rightarrow$ Learning of adverse implications of virus for infant health $\rightarrow$ Considerations about candidates' competencies $\rightarrow$ Increased support for female candidates

First, a subset of Brazilian voters is exposed to the Zika virus during an electoral season. Second, voters rationally seek out information about the virus and its adverse implications. Third, upon learning about the detrimental implications of the virus for infant health, voters consciously or subconsciously activate heuristics to help them understand which types of political candidates are most adept policy makers in the areas of infant health. Finally, using rational prospective voting informed by gender-stereotype-based heuristics, voters cast their ballots in favor of female mayoral candidates. In what follows, we provide evidence of these four steps.

\section{Electoral season exposure to Zika}

Since its most recent democratic transition, Brazil has held regularly scheduled local, state, and national elections. Local contests elect mayors and municipal representatives, and state and national contests elect presidents, governors, senators, and state and federal representatives. Local, state, and national elections are held every four years, but local contests are separated from state and national elections by two years. Brazil held local elections in 2016, a year dominated by a Zika epidemic-induced national emergency and

\footnotetext{
${ }^{2}$ As Schwindt-Bayer (2006) suggests, observed differences in the behaviors of male and female politicians may not necessarily reflect disparate preferences but a systemic treatment of gender. Kittilson and Fridkin (2008), for example, found that the press covers male and female political candidates differently. However, many studies discern minimal attitudinal differences across male and female politicians (La Cour, Dabelko, and Herrnson 1997; Dolan 2005; Lovenduski and Norris 2003).
} 
immense public concern with the virus. Although outbreaks of the Zika virus were primarily concentrated in the Northeast and Center-West, the epidemic reached all of the country's regions. Figure $\mathbf{1}$ depicts the spatial distribution of the reported total number of cases of the Zika virus in municipalities in each of Brazil's five regions.

In total, 170,535 Zika cases were reported in 2016 (BBC 2017) and by April 30, 2016, 1,912 cases of microcephaly-a devastating condition linked with the Zika virus and marked by abnormalities in infants' head size and brain development-were reported. Victims of microcephaly are understood to experience seizures, developmental delays, intellectual disabilities, difficulties with movement and feeding, as well as hearing loss and vision problems. These injurious effects cripple the lives of babies with microcephaly and may prove life threatening. ${ }^{3}$ The virus-generated outbreak of microcephaly attracted the widespread attention of the Brazilian public and compelled Brazilians to rationally seek out information about the unfamiliar epidemic.

\section{Learning of adverse implications for infant health}

Figure 2 shows 2015 and 2016 Google searches from Brazil on the Zika virus as well as on two other infectious diseases transmitted by the Aedes aegypti mosquito (the mosquito that transmits the Zika virus), Chikungunya and Dengue. This figure indicates that, prior to the first reported case of Zika in Brazil in May 2015, there were virtually no internet searches for the Zika virus in the country. The number of Zika searches initially peaked in November 2015, the month in which the Brazilian government declared a national emergency. In the "mosquito season" summer months of the following year, searches on Zika reached unprecedented levels. In early 2016, searches on the Zika virus outnumbered those on Chikungunya. Although searches on Dengue outnumbered searches on Zika in raw number, in terms of the ratio of searches to reported cases, the public did significantly more research on the Zika virus. In the first four months of 2016, the number of reported cases of Dengue in Brazil was approximately seven times greater than the number of reported cases of Zika (BBC 2017; Herriman 2016). The normalized scores of searches for Dengue in the same period, by contrast, was less than double the normalized scores

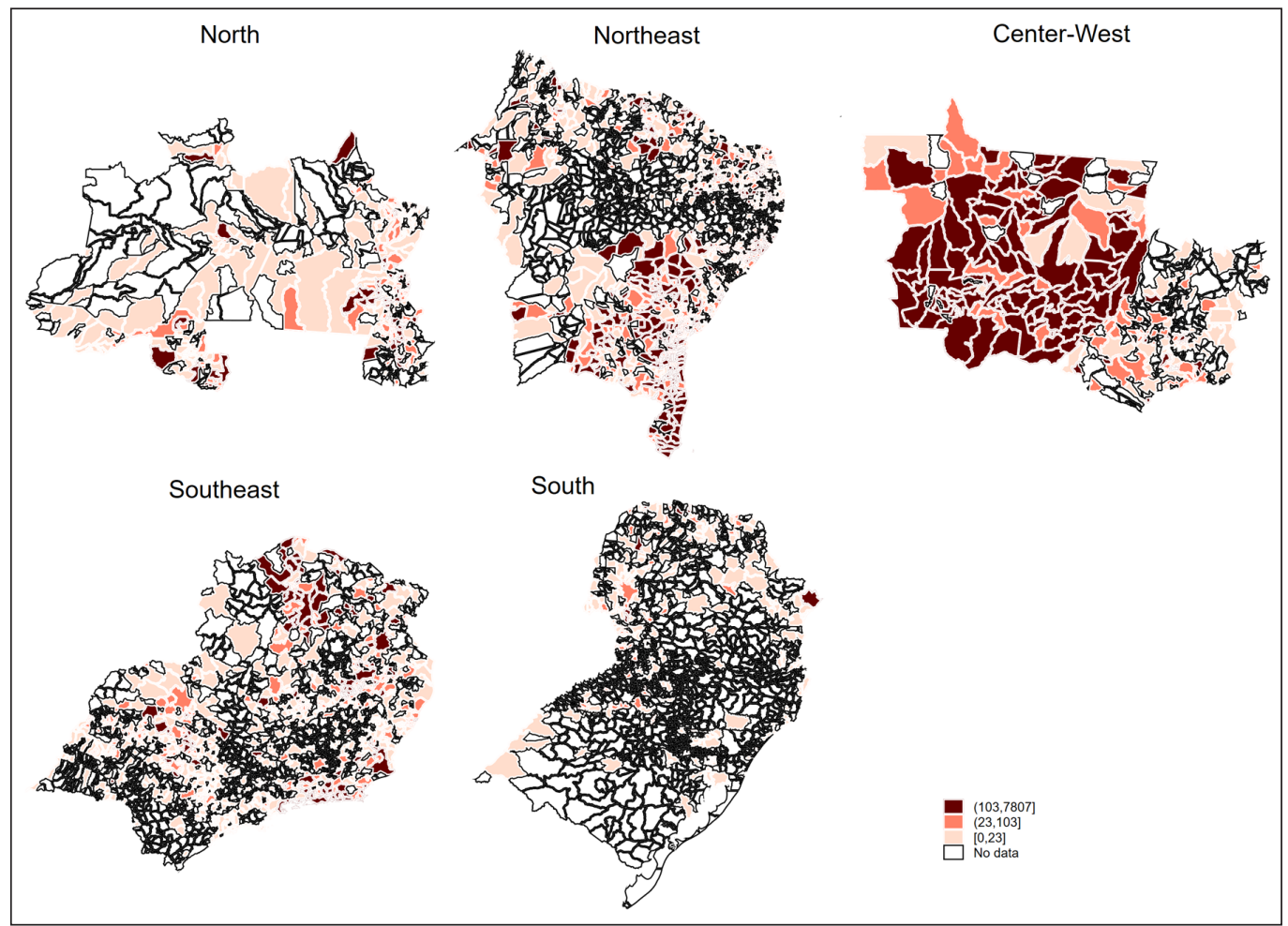

Figure 1: Cases of Zika per 100,000 people in 2016 by Brazilian region. Municipalities are distinguished by quartiles associated with the number of reported cases of the Zika virus in 2016. The darker the shading, the higher the number of reported cases of Zika. Municipalities shaded in white had no reported cases.

\footnotetext{
${ }^{3}$ For more about microcephaly, see the website of the US Centers for Disease Control and Prevention, https://www.cdc.gov/ncbddd/ birthdefects/microcephaly.html.
} 


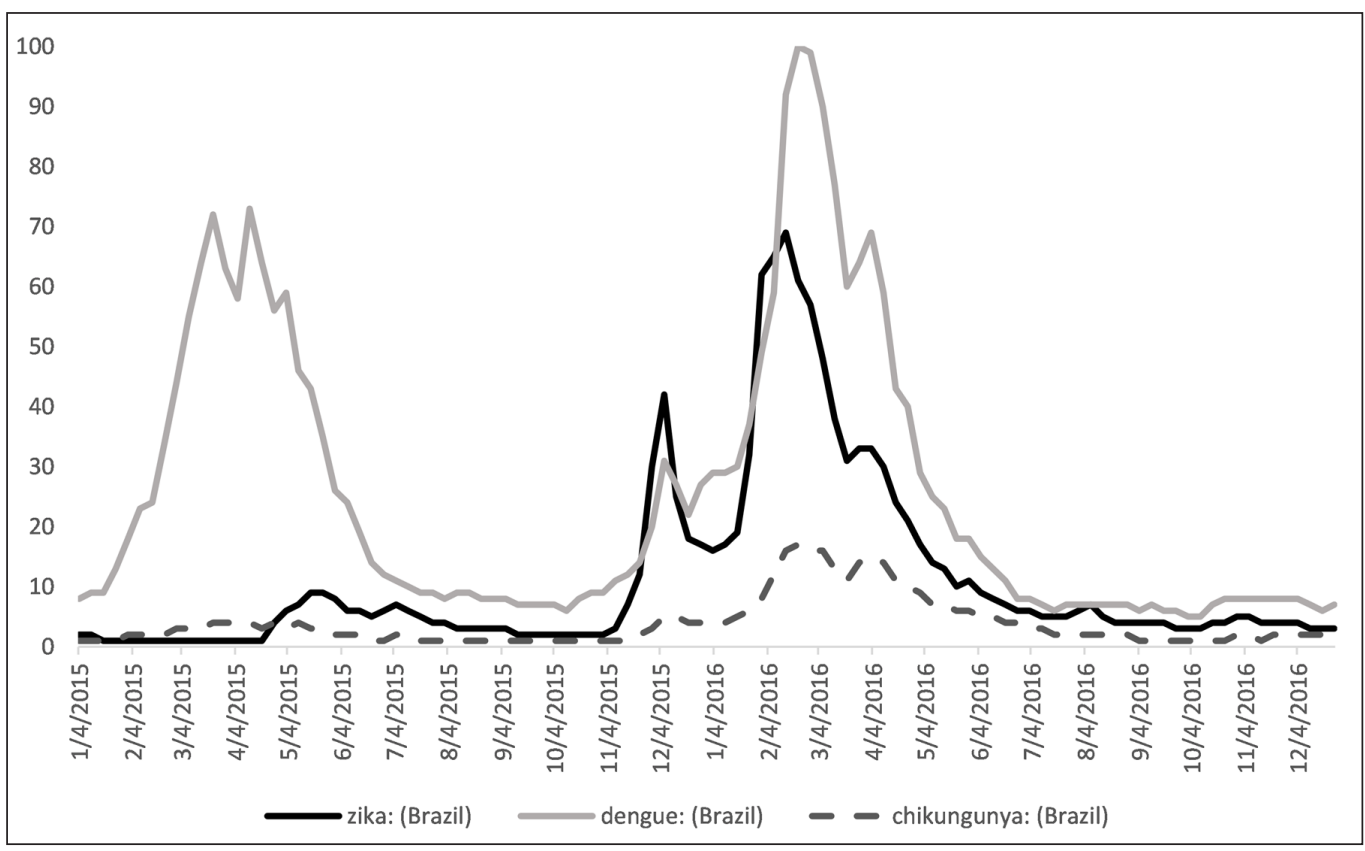

Figure 2: Google searches for Zika, Chikungunya, and Dengue. Normalized scores of search intensity; 100 indicates peak intensity for given search terms.

of searches for Zika. We interpret this as a strong signal that the public sought out information about the Zika virus. The ubiquity of information available connecting the virus to microcephaly permits us to make the logical inference that Zika-informed Brazilian voters connected the virus with adverse implications for infant health in advance of the 2016 elections. ${ }^{4}$

The Latin American Public Opinion Project (LAPOP) provides us with the resources to confirm that exposure to and rationally conducted research about the virus instilled in Brazilian voters the intimate connection between the virus and risks to infant health. ${ }^{5}$ We use pertinent data from the 2017 LAPOP survey wave to assess whether survey respondents with personal exposure to Zika (i.e., respondents who either were diagnosed themselves or had someone close to them diagnosed with the virus) were more likely to perceive Zika as a serious threat to public health.

To do this, we implement a logistic regression analysis to estimate the effect of exposure to Zika on the probability of a respondent considering Zika to be a serious or very serious threat to health. ${ }^{6}$ The results depicted in Table 1 confirm that exposure to Zika increases concern with the virus.

Our results suggest that voters exposed to Zika are 1.33 times more likely to consider Zika to be a serious threat to health in Brazil than their counterparts without exposure to the virus. This outcome requires Zika-exposed voters to have responded rationally to the emerging epidemic and to have judiciously sought out and acquired information about the virus. Exposure to, knowledge about, and concern with the virus plausibly led voters to factor the virus into their 2016 political decision-making calculations.

\section{Considerations of candidates' competencies}

Despite the overlap between the Zika epidemic and Brazil's 2016 electoral season, few Brazilian mayoral candidates discussed the issue in their campaigns (O Globo 2016). ${ }^{7}$ This silence is especially puzzling given that Brazilian municipalities are partially responsible for controlling outbreaks of the virus and that mayors are the principal actors entrusted with legal, budgetary, and administrative matters within their

${ }^{4}$ Anecdotal evidence from an Exam magazine interview with the mayor of Recife (the Brazilian municipality with the largest number of Zika-induced microcephaly cases) lends support to our inference. In this interview, the mayor explains his role in the development of vast awareness campaigns aimed at informing the public and decreasing the number of cases of the Zika virus (Exame 2016). Assuming that such awareness campaigns were effective, it is logical to suspect that voters were aware of the intimate connection between Zika and the adverse effects of the virus for infant health on the eve of elections.

${ }^{5}$ LAPOP has conducted public opinion surveys in Brazil every two years since 2006.

6 The specific question asked was, "What is the risk of Zika to health in Brazil?"

${ }^{7}$ For instance, Boas and Hidalgo (2019) suggest that in the state of Pernambuco (the Brazilian state with the most cases of microcephaly per 100,000 people), only 5 percent of candidates running for mayor mentioned the Zika virus in their campaign platforms. 
Table 1: Effect of exposure to Zika on concern with the virus.

\begin{tabular}{lr} 
Variable & $\mathbf{( 1 )}$ \\
\cline { 2 - 2 } Exposure & Zika is a serious threat \\
& $0.305^{* *}$ \\
Observations & $(0.156)$ \\
\end{tabular}

Note: This regression controls for gender and age.

${ }^{* * *} p<0.01$; ${ }^{* *} p<0.05$; $^{*} p<0.1$.

jurisdictions (Wampler 2004). ${ }^{8}$ Campaign silence on the issue meant that voters concerned with the virus were left to their own devices to discern which candidates would best address pressing challenges to infant health generated by the virus.

In an environment with limited information about candidates' stances on both the virus and the appropriate methods of response, a large body of extant research on voter behavior suggests that Brazilian voters likely would have activated heuristics to help them make informed decisions. ${ }^{9}$ More concretely, the gendered nature of the Zika-primed issues suggests that voters likely would have considered gender stereotypes relating to issue competencies. As described previously, female politicians are typically perceived as more adept policy makers in areas relating to infant health and family matters than their male counterparts are (Leeper 1991; Alexander and Anderson 1993; Huddy and Terkildsen 1993; Herrnson, Lay, and Stokes 2003; Brollo and Troiano 2016). Insofar as this global stereotype extends to Brazil in light of the Zika virus, Brazilian voters would plausibly have come to the conclusion that female mayoral candidates were better equipped than their male counterparts to respond to the virus-imposed challenges to infant health. ${ }^{10}$ In the section that follows, we assess the implication of this and the expected result of rational prospective voting in light of an indiscriminate epidemic.

\section{Greater support for female mayoral candidates}

In an effort to assess whether Brazilian voters practiced rational prospective voting in response to the Zika epidemic, we estimate the effect of exposure to the virus on support for female mayoral candidates. We focus on mayoral elections because Brazilian mayors are charged with developing and overseeing policies to control and respond to the outbreak of Zika. If Brazilian voters did, in fact, practice rational prospective voting, voters in Zika-prone areas will have voted in favor of female candidates at higher rates than voters residing in less Zika-prone areas.

To supplement our primary analysis, we also conduct placebo tests to capture the influence of potential endogenous factors related to the number of vector-borne mosquitos in Brazilian municipalities (e.g., underdevelopment, poor sanitation quality, climate). These tests allow us to assess whether the relationship between Zika-prone municipalities and support for female candidates exists through a channel other than that advanced in this article. Our placebo tests consider Chikungunya and Dengue. Chikungunya and Dengue are diseases transmitted by the same mosquito as that transmitting Zika (Aedes aegypti) but without adverse implications for pregnancy and infant health. If our logic holds, exposure to these viruses should not affect support for female politicians. To reiterate, we posit that exposure to the Zika virus will increase support for female candidates through rational prospective voting achieved through the activation of gender stereotype-based heuristics. Our placebo tests test the robustness of this argument.

To test our hypotheses, we collected municipality-level monthly data reports of Zika, Chikungunya, and Dengue cases for 2016 from the information technology department of the Brazilian Unified Health System (DATASUS) and data on the gendered distribution of the vote share from the 2012 and 2016 Brazilian mayoral

\footnotetext{
${ }^{8}$ Brazilian legislatures are primarily reactive. At the local level, their primary role in local policy making is to veto legislation proposed by the mayor (Wampler 2004). Given this, it would have been incumbent on Brazilian mayors to generate political responses to the Zika-induced crisis

${ }^{9}$ See Steenbergen and Colombo (2018) for a review of this literature.

${ }^{10}$ In Appendix Table A1, we further test this claim through examining whether LAPOP survey respondents exposed to the Zika virus were more prone to strongly disagree with the statement that men are better politicians than women than survey respondents without exposure to the virus. Assuming concern with the virus among the exposed respondents and all else equal, disagreement in the gendered political evaluations across Zika-exposed and non-Zika-exposed respondents would signal activated gender stereotypes relating to health.
} 
elections from the Superior Electoral Court. ${ }^{11}$ This data permits us to study the relationship between exposure to the Zika virus and the female vote share and to confirm that confounding variables related to the transmitting Aedes aegypti mosquito do not manufacture a spurious relationship. To assess our relationship of primary interest between exposure to the Zika virus and the female vote share, we implement difference-in-difference analyses with a continuous treatment variable following Acemoglu, Autor, and Lyle's (2004) example.

Difference-in-difference analyses are valuable for the enterprise of assessing whether and the conditions under which exposure to an indiscriminate epidemic with gender-based issue implications influences the gendered vote share given that they control for the possibility of differences in baseline preferences regarding candidate gender..$^{12}$ Although to our knowledge gender disparities in baseline preferences have not been investigated in the Brazilian context, the revelation of such preferences in alternative contexts renders it necessary to account for the possibility in our analysis (Sanbonmatsu 2002; Bauer 2015).

Specifically, we estimate variants of the following difference-in-difference model for each of the twelve months in 2016:

$$
\text { VoteShare }_{m t}=\alpha+\beta_{1} \text { Post }_{t}+\beta_{2} \text { Post }_{t} * \log \left(\text { Zika }_{m}\right)+\beta_{3} X_{m t}+\Lambda_{m}+\epsilon_{m t},
$$

where VoteShare ${ }_{m t}$ represents the vote share for female mayoral candidates in municipality $m$ and election year $t$ (2012 or 2016), given that municipality $m$ had female mayoral candidates in both election years and had at least one Zika case reported in the 2016 month corresponding with the model. ${ }^{13}$ Post $_{t}$ is a dummy variable equal to 1 when $t=2016$ and 0 otherwise, and $\log \left(Z i k a_{m}\right)$ is the logarithm of the number of reported cases of Zika per 100,000 residents in municipality $m$ in the 2016 month corresponding with the model. Vector $X_{m t}$ includes population, gross domestic product per capita, the vote share for female municipal council candidates, and municipal ideology as control variables. ${ }^{14} \Lambda_{m}$ represents municipal fixed effects. Finally, $\epsilon_{m t}$ is the error term. The coefficient $\beta_{2}$ is the primary parameter of interest. It represents the effect of the Zika virus on the vote share for female mayoral candidates. We estimate similar models albeit with $\log \left(\right.$ Chikungunya $\left._{m}\right)$ and $\log \left(\right.$ Dengue $\left._{m}\right)$ substituted for $\log \left(Z i k a_{m}\right)$ to conduct our placebo tests.

Figure 3 contains the results of our primary difference-in-difference analyses. Our results suggest that the relationship between Zika outbreaks in the months leading up to the 2016 Brazilian mayoral elections and support for female mayoral candidates is positive and statistically significant. If the number of cases of Zika per 100,000 residents increases by 10 percent in August and September combined, then the vote share for female mayoral candidates is predicted to increase by 0.579 percent (Appendix Table A2). ${ }^{15}$ By contrast, cases of Zika reported both earlier in the year and after Election Day (October 2) do not influence support for

${ }^{11}$ DATASUS provides data on reported cases of Zika beginning in 2016. Although our data may fail to capture some of the earliest (unreported or underreported) cases of the virus, our finding that only exposure to the virus in the months immediately preceding the 2016 municipal elections influences the female vote share makes us less concerned with missing data from earlier periods. We use population data collected from the Brazilian Institute of Geography and Statistics (IBGE) to construct a variable of monthly cases of Zika per 100,000 people at the municipality level. We also rely on data from the aforementioned sources for the control variables included in our model.

12 A main threat to our analysis is that per capita income might be negatively correlated with number of Zika cases in each municipality. If this is the case, then because income is associated with electoral outcomes, our results could be biased. However, we found that municipalities do not have statistically significant differences in per capita income across reported levels of Zika cases. Our results are unchanged regardless of whether we account for all Zika cases reported in 2016 or restrict our sample to Zika cases reported in the two months prior to the 2016 local elections.

${ }^{13}$ Restricting our sample solely to municipalities that had female mayoral candidates in both 2012 and 2016 elections could introduce selection bias. Specifically, it could result in an analysis confined solely to municipalities with more positive assessments of female candidates. We mitigate this concern by assessing whether municipalities in our sample had greater support for female municipal council candidates in the baseline (i.e., 2012) in comparison to the rest of Brazil (i.e., municipalities not included in our sample). We find that municipalities in our sample actually have one-fifth of a standard deviation smaller support for female municipal council candidates (significant at the 99 percent level) than the remaining municipalities. This serves to reduce concerns associated with selection bias.

${ }^{14}$ In exploratory exercises, we confirmed that there is no relationship between the number of reported cases of the Zika virus and the vote share for female candidates competing for seats on the municipal council. This ensures that we are not introducing post-treatment bias into our model with the inclusion of the vote share for female municipal council candidates as a control variable. Adding the vote share for female municipal council candidates helps us control for potential omitted variables related to preferences for female candidates that can vary over time and across municipalities. We obtain the data associated with socioeconomic, electoral, and political ideology variables, respectively, from the IBGE, Superior Electoral Court, and Power and Rodrigues-Silveira (2019).

15 Substituting the vote share dependent variable with a dichotomous variable representing the gender of the elected candidate, we find that if the cases of Zika per 100,000 residents increases by 10 percent in August and September combined, then the probability that a female mayoral candidate wins office increases by 0.009 percent. This result is significant at the 5 percent level and is available upon request. 


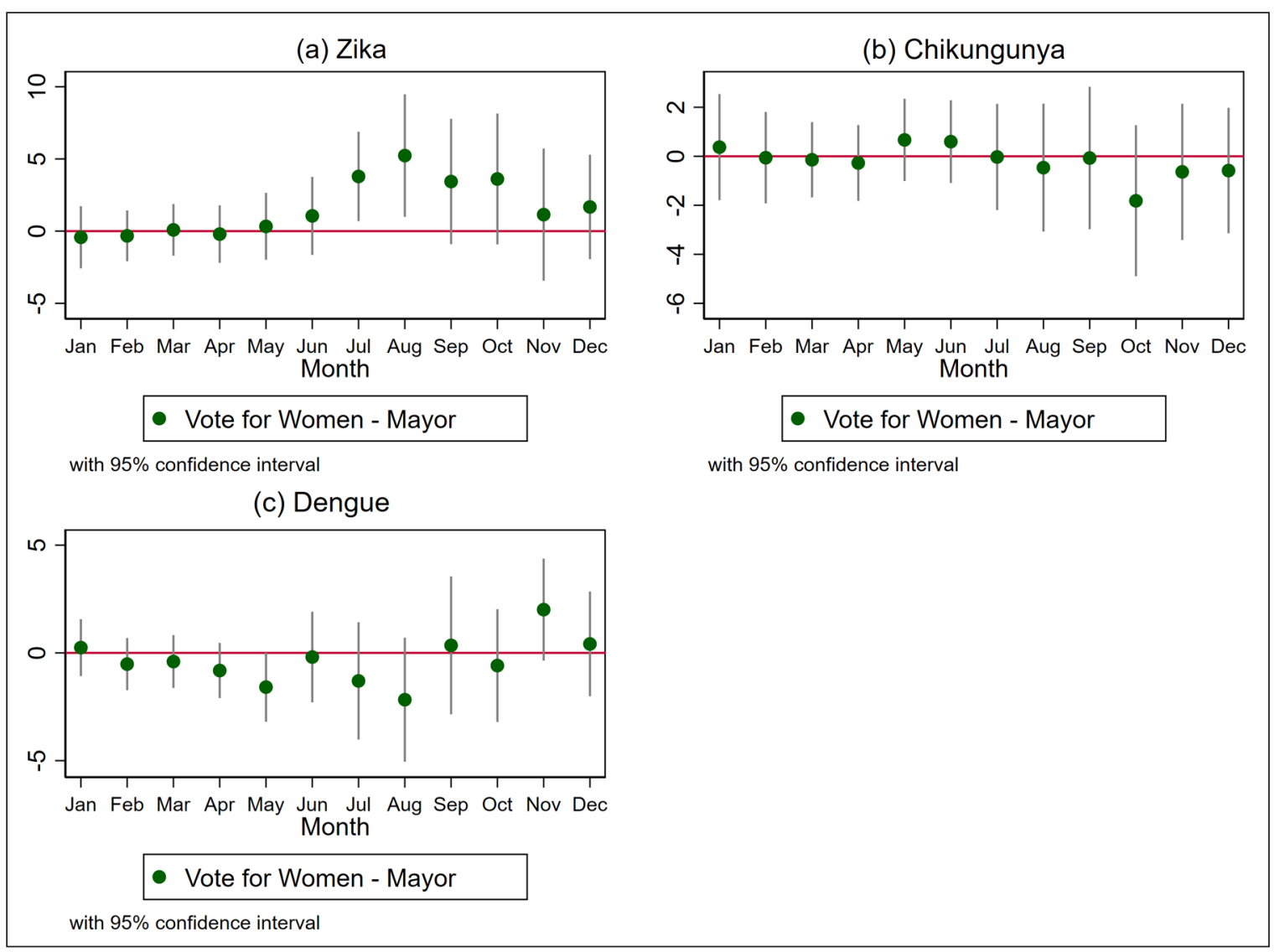

Figure 3: Impact of cases of Zika, Chikungunya, and Dengue on support for female mayoral candidates. Vertical black lines represent 95 percent confidence intervals.

female mayoral candidates. These results confirm the utility of rational prospective voting in this Brazilian electoral climate. Further supporting this evidence is the fact that we do not find any significant effects of reported cases of Chikungunya and Dengue on the share of the vote cast for female mayoral candidates. The results of our placebo tests permit us to rule out the possibility that confounding variables relating to the transmitting Aedes aegypti mosquitos drive our primary results, thus substantiating the logic advanced in this article. Robustness checks further promote our argument.

\section{Robustness Checks, Falsification Tests, and Alternative Explanations}

In an effort to provide additional evidence supporting our argument that exposure to the Zika virus activates rational prospective voting, we re-estimate our primary models with a sample restricted to cases of Zika among pregnant women reported in August and September combined. If our anticipated mechanism-that Brazilians exposed to the virus vote based on the perception that Zika is a "women's issue" due to its link to infant congenital disabilities-is correct, then we should observe larger effects of exposure to Zika on the female vote share in municipalities with high incidence of the virus among pregnant women. We also should not observe any relationship between exposure to Chikungunya and Dengue and the female vote share.

Table 2 confirms our expectations. Column one suggests that the relationship between public exposure to the Zika virus and support for female mayoral candidates is positive and statistically significant when the analysis is restricted to consider solely municipalities with infected pregnant women. Additionally, it communicates that the effect of reported cases of Zika on the electoral support for female mayoral candidates is larger in magnitude when the analysis is restricted to consider solely municipalities with infected pregnant women (as compared to all municipalities with reported cases). If the number of reported cases of pregnant women diagnosed with Zika per 100,000 residents increases by 10 percent, then the vote share for female mayoral candidates is predicted to increase by 0.95 percent. By contrast, reported cases of Chikungunya or Dengue among pregnant women do not influence the female vote share. ${ }^{16}$ These findings provide additional evidence in favor of rational prospective voting in response to an indiscriminate epidemic.

${ }^{16}$ The complete model is reported in Appendix Table A3. 
The main identification assumption of difference-in-differences analyses is the anticipated presence of parallel trends in outcomes in the absence of treatment. Although our analysis in Figure $\mathbf{3}$ reassures this requirement-as prior to July, Zika-prone areas did not show significantly more support for female candidates than less affected areas-we provide additional evidence of parallel trends by computing the percent of votes received by female candidates in 2008 and, subsequently, measuring whether or not disease outbreaks in 2016 predict the difference in the female vote share between 2008 and 2012. Our results indicate that municipalities with Zika outbreaks in 2016 did not exhibit trends of increasing female political success prior to 2016. Put differently, our analysis suggests that prior to the intervention of the virus, Zika-exposed and non-Zika-exposed municipalities exhibited parallel political trends. Table 3 contains our results. ${ }^{17}$

In our final effort to introduce evidence of rational prospective voting in light of the Zika epidemic, we dispel alternative explanations that could underlie our results. Our main argument is that, in the face of the Zika epidemic, Brazilian voters used rational prospective voting. We posit that rational prospective voting led Brazilian voters to utilize gender stereotypes relating to the "women's issue" of congenital health to make electoral decisions and to provide increasing support to female political candidates (Brollo and Troiano 2016). Our theoretical framework differs from that highlighted in a previously reviewed, robust literature that discerns retrospective voting behaviors in light of indiscriminate events relating to the weather (e.g., Cole, Healy, and Werker 2012; Fuchs and Rodriguez-Chamussy 2014; Gasper and Reeves 2011; Fair et al. 2017), shark attacks (Achen and Bartels 2004a), or sporting events (Healy, Malhotra, and Mo 2010; Miller 2013). Throughout this article, we have dismissed the possibility that exposure to the Zika virus activated retrospective voting. In this section, we test this alternative theoretical supposition directly.

The rich literature on retrospective voting in light of haphazard events would predict that aggrieved voters exposed to the Zika virus would sanction incumbent politicians. If incumbents in municipalities with greater exposure to the Zika virus were disproportionately male, then our findings might simply reflect voters' haphazard punishment of male candidates. In what follows, we demonstrate that areas with greater exposure to the Zika virus were not more likely to have had male incumbents. In doing this, we confirm the unlikelihood of voters irrationally punishing male incumbents out of frustration relating to the Zika virus instead of rewarding female policy makers with perceived competencies in the area of infant health. Our finding goes against the conventional wisdom of retrospective voting in light of indiscriminate circumstances.

Table 2: Effect of public exposure to Zika, Chikungunya, and Dengue on share of the vote for female mayoral candidates restricted to municipalities with infected pregnant women.

\begin{tabular}{lcrr} 
Virus variables & $\mathbf{( 1 )}$ & \multicolumn{1}{c}{$(\mathbf{2})$} & \multicolumn{1}{c}{$\mathbf{( 3 )}$} \\
\cline { 2 - 4 } & \multicolumn{1}{c}{ Zika } & Chikungunya & \multicolumn{1}{c}{ Dengue } \\
\hline Post $\times \log ($ Virus $)$ & $9.621^{* *}$ & 1.082 & 3.258 \\
& $(3.693)$ & $(2.984)$ & $(3.647)$ \\
Observations & 128 & 121 & 112 \\
\hline
\end{tabular}

Note: Regressions consider number of cases of each disease per 100,000 residents in August and September combined. ${ }^{* * *} p<0.01{ }^{* *} p<0.05 ;^{*} p<0.1$.

Table 3: Effect of exposure to Zika, Chikungunya, and Dengue on share of the vote for female mayoral candidates, falsification test (2008 vs. 2012).

\begin{tabular}{lrrr} 
Virus variables & \multicolumn{1}{c}{$(\mathbf{1})$} & $\mathbf{( 2 )}$ & \multicolumn{1}{c}{$\mathbf{( 3 )}$} \\
\cline { 2 - 4 } & \multicolumn{1}{c}{ Zika } & \multicolumn{1}{c}{ Chikungunya } & \multicolumn{1}{c}{ Dengue } \\
\hline Post $\times \log ($ Virus $)$ & 0.090 & 1.139 & $-2.285^{*}$ \\
& $(2.152)$ & $(1.343)$ & $(1.286)$ \\
Observations & 325 & 667 & 941 \\
\hline
\end{tabular}

Note: Regressions consider number of cases of each disease per 100,000 residents August and September combined. ${ }^{* * *} p<0.01$; $^{* *} p<0.05$; $^{*} p<0.1$.

${ }^{17}$ Appendix Table A2 reports the full model. 
Retrospective voting could also operate and underlie our observed primary results in more dubious ways. If political parties-anticipating conventional retrospective voting and the accompanying punishment of male incumbent politicians-proactively nominated or provided additional financial support to female candidates, these actions, too, could serve as signals of retrospective voting at work. We consider these two possibilities in turn.

A robust literature on strategic politics and political ambition suggests that potential candidates condition their decision to compete for office on their evaluated propensities of winning. ${ }^{18}$ Numerous factors contribute to political candidates' propensities for success. Among these, political-party nomination and backing are fundamental. Recent literature shows that, at least in the context of Latin America, political parties are increasingly likely to nominate female candidates when confronted with electoral environments that bode poorly for male candidates (e.g., environments characterized by widespread public distrust and pervasive corruption) (Funk, Hinojosa, and Piscopo 2017, 2019). Insofar as the Zika virus fostered a similar environment, it is plausible that it altered political-party gatekeepers' strategic calculations surrounding political nominations to the benefit of female candidates. On the basis of this logic, one might suspect that the Zika virus would, by way of political-party nominations, alter female candidates' calculations to contest political office. However, in our forthcoming analysis, we show that this was not the case; women were not more likely to contest mayoral elections in municipalities with more reported cases of the Zika virus.

In another effort to consider more dubious retrospective voting mechanisms, we consider the probable reality that campaign funding discrepancies across candidates disparately affected by the Zika virus underlie our observed results. That money drives politics is common knowledge. This relationship is especially pronounced in democratic societies with comparatively expensive elections. In Brazil-where elections are among the most expensive in the world (Mainwaring 1999; Samuels 2001)-Samuels (2001) finds that candidates with more financial resources do better than candidates with fewer financial resources. It is plausible that the Zika-permeated climate surrounding the 2016 elections in Brazil impacted political parties' strategic calculations not only on who to nominate but also on how to optimally distribute financial resources. Along these lines, it is possible that political parties made resources disparately available to female candidates on the basis of their municipalities' levels of exposure to the Zika virus and, by doing so, differentially impacted female candidates' propensities of electoral success.

However, forthcoming analyses designed to probe these alternative explanations confirm that women running for mayor in municipalities with more reported cases of Zika did not have disproportionately more financial resources than their counterparts in municipalities with less reported cases of Zika. If well-funded female candidates were more likely to compete in municipalities with more cases of Zika because they perceived that these municipalities would offer them better opportunities to be elected, then our results would be biased upward; municipalities with higher incidences of Zika would also have wealthier female candidates who were more equipped to win elections. However, we show that the financial resources of female mayoral candidates, on average, were similar across municipalities with disparate levels of exposure to the Zika virus. This result further confirms that neither retrospective voting nor the anticipation of it underlies our observed results.

Aside from alternative explanations related to retrospective voting theories, it is plausible that our primary result of a positive relationship between exposure to the Zika virus and support for female candidates may be driven by increasing support for abortion and political parties with pro-abortion stances or by obscure virus-motivated electoral turnout patterns. In what follows, we document the logic underlying and the literature supporting each of these alternative explanations and foreshadow the minimal empirical support we find to back them.

We consider the possibility that instead of increasing support for female candidates as a function of rational prospective voting, Brazilian voters' increased support for female candidates stemmed from a purposeful uptick in support for pro-abortion political parties (many of which also advocate for the increased political representation of women). Research finding that the Zika virus had a fertility-depressing effect (Senters and Schneider 2019) conjectures that the Zika epidemic also influenced support for abortion. Further supporting this presumption is research by Aiken et al. (2016) finding that, in light of the Zika virus, Latin Americans' abortion requests to Women on Web skyrocketed and, at the height of the epidemic, Brazilians discussed the possibility of legalizing abortion for pregnant women diagnosed with the virus. ${ }^{19}$ Rodrigo Janot, Brazil's

\footnotetext{
${ }_{18}$ For a review of this literature, see Shafer (2018).

19 Women on Web is a nonprofit organization that provides informal access to abortion medications to pregnant women in countries where safe abortion is not legally permitted. Abortion is only permitted in Brazil if pregnancy threatens the mother's life or if the conception is a result of rape.
} 
then attorney general, went so far as to initiate a bill in September 2016 to legalize abortion for pregnant women diagnosed with Zika (Veja 2016). If voters exposed to Zika were disproportionately likely to favor pro-abortion policies-as Cohen and Evans (2018) found-and to support pro-abortion parties, and if women were disproportionately likely to belong to these parties, then our results would be overestimated.

However, our analyses show that exposure to Zika did not influence preferences for pro-abortion parties with which female candidates may have been more commonly affiliated. We demonstrate that exposure to Zika does not predict support for pro-abortion parties. This result suggests that voters privileged candidates capable of responding to existing problems to infant health over parties committed to inducing change that would mitigate similar future challenges.

Finally, we consider the possible operation of obscure virus-motivated turnout patterns. If voters with more exposure to Zika were more concerned about the virus, it is plausible that this concern may have mobilized them to turn out to vote and to support female candidates and that voters with less exposure to the virus were no more mobilized than usual. Insofar as exposure to Zika is a mobilizing force for nonregular voters in municipalities with more exposure to the virus, it could explain the observed relationship between the virus and the female vote share. However, we show that turnout is unaffected by exposure to Zika and, therefore, is unlikely to underlie our primary observed relationship. Given that voting is mandatory in Brazil, this finding was to be expected, but this confirmation provides additional support for our main argument.

We consider and dispel each of the aforementioned alternative explanations with similar difference-indifference models to those used in our primary empirical analysis. The models used in this section are variants of Equation 1, albeit with dependent variables corresponding with our considered alternative explanations. The data associated with our dependent variables comes from the Superior Electoral Court and Duke University's Democratic Accountability and Linkages Project. ${ }^{20}$ Table 4 contains these results.

As Table 4 depicts, none of the introduced alternative explanations are supported. In Table $\mathbf{4}$, we show that incumbent mayors in Zika-prone areas were not more likely to be male. We also show that political parties in Zika-prone areas are neither more likely to support female candidates nor to financially invest more in them. These results dispel the possibility that retrospective voting underlies our result of a positive relationship between exposure to the Zika virus and support for female candidates. In Table 4, we show that pro-abortion parties did not receive significantly more support in Zika-prone areas. Finally, we show that turnout is unaffected by exposure to the virus. In sum, these results increase confidence in our supposition that gender stereotypes relating to issue competencies underlies our observed relationship between Zika exposure and the female vote share and that, in the face of the Zika virus, Brazilian voters utilized rational prospective voting. ${ }^{21}$

\section{Discussion and Conclusion}

Recent political behavior scholarship has questioned often-made assumptions of voter rationality through studies of electoral behavior in light of haphazard, apolitical events. These studies' findings deduce that grieving voters sanction incumbent politicians for events or outcomes largely outside of incumbent

Table 4: Dispelling alternative explanations underlying the relationship between exposure to Zika and the vote share of female candidates.

\begin{tabular}{|c|c|c|c|c|c|}
\hline \multirow[t]{2}{*}{ Variables } & (1) & (2) & (3) & (4) & (5) \\
\hline & Male incumbent & $\begin{array}{c}\text { Number of female } \\
\text { candidates }\end{array}$ & $\begin{array}{l}\text { Financial } \\
\text { resources }\end{array}$ & $\begin{array}{c}\text { Against } \\
\text { abortion }\end{array}$ & $\begin{array}{l}\text { Voting } \\
\text { turnout }\end{array}$ \\
\hline \multirow[t]{2}{*}{ Post $\times \log ($ Virus $)$} & 0.019 & 0.223 & $-4,966$ & 0.049 & -0.001 \\
\hline & $(0.040)$ & $(1.642)$ & $(25,784)$ & $(0.151)$ & (0.003) \\
\hline Observations & 351 & 348 & 168 & 352 & 352 \\
\hline
\end{tabular}

Note: Regressions consider number of cases of Zika per 100,000 residents in August and September combined. ${ }^{* * *} p<0.01 ;{ }^{* *} p<0.05 ;{ }^{*} p<0.1$.

${ }^{20}$ Duke University's Democratic Accountability and Linkages Project classifies each Brazilian political party on a scale of 1 to 10 on the basis of their positions relating to abortion. A value of 1 on this scale indicates support for abortion, and a value of 10 indicates opposition to abortion. We use this abortion classification to weight the vote share of each party the municipality level.

21 The online appendix provides confirmation that the treatment and control groups are comparable in terms of electoral outcomes. 
control. We revisited this finding to determine whether, instead of invoking irrational responses, such indiscriminate events can sometimes induce voters to practice rational prospective voting. We evaluated the operation of rational prospective voting through studying the politics of the Zika virus.

Specifically, we leveraged the quasi-random experiment afforded by the indiscriminate outbreak of the 2015-2016 Zika epidemic to estimate the effect of the virus and its primed salience of the "women's issue" of infant health on political support for female candidates in the 2016 Brazilian local elections. With difference-in-difference analyses, we demonstrated that areas with higher incidences of Zika in the months immediately preceding the 2016 local elections witnessed greater increases in the female vote share in between the 2012 and 2016 elections than areas with lower incidences of the virus. We further confirmed the validity of our results by demonstrating the robustness of our results, the compelling satisfaction of regression assumptions, and the incredibility of alternative explanations.

Our results confirm that, in light of indiscriminate events with adverse consequences, voters do not always default to vote retrospectively and to sanction incumbent politicians. Instead, they suggest that, when confronted with pressing challenges outside of incumbent control, voters may vote both rationally and prospectively. To our knowledge, this finding is largely unprecedented, especially in the context of the developing world in which less mature voters are sometimes assumed to exhibit more erratic electoral behaviors. Moreover, it confirms that normative democratic electoral behaviors are not out of reach, even in developing contexts. Beyond elucidating the complex calculations underlying voting behavior, we shed light on the ill-understood circumstances that lead Latin Americans to apply gender stereotypes when assessing their political leaders (Setzler 2019) and, arguably more pointedly, the conditions favorable to female candidates' electoral prospects. Increasing the political representation of women is understood to be an important requisite for mitigating pervasive gender inequalities and is, consequently, a global policy priority. Despite near-ubiquitous commitment to enhancing female political representation, progress on this front has remained slow (especially in the Latin American context; see Basabe-Serrano 2020). While gender electoral quotas, for example, have helped spur some advances in female representation (Wylie 2018; Sacchet 2018), they have not proved be-all, end-all solutions to the challenge of female underrepresentation in politics (Htun 2002).

Insofar as the priming of "women's issues" results in favorable electoral prospects for female politicians, political gender imbalances may be mitigated in the short run. If women elected in response to the (un) intended priming of "women's issues" prove their capabilities once in office and incur additional public support as a result, the priming of "women's issues" may instill increased political representation in the longer term. ${ }^{22}$ Speaking to this, Speck $(2018,57)$ finds that "in the municipalities in which a female mayor was elected, the probability of having first-time female candidates in the next election is 1.8 times higher than in the last electoral contest." If future research investigates and determines that women are proactive in their mandates to address the challenges that contributed to their election (e.g., female candidates elected in response to the emerging challenges associated with the Zika virus), ${ }_{,}^{23}$ female candidates ought to claim ownership and continuously raise the salience of issues that voters perceive them to be especially adept at addressing. In sum, the Zika virus and accompanying priming of "women's issues" serves as an important example of a circumstance with the potential to generate both short- and long-term yields for women's political representation.

Although we have focused on evaluating the utility of rational prospective voting in the Brazilian context because of the opportunity to do so afforded to us by the quasi-random Zika outbreak, we believe that our results generalize beyond Brazil. We expect that voters might practice rational prospective voting to the benefit of political candidates with perceived competencies on primed issues more broadly. We anticipate this type of electoral behavior to be particularly prevalent in countries with institutions that, like Brazil's, empower individual politicians vis-à-vis political parties and incentivize political candidates to cultivate the personal vote (e.g., open-list proportional representation systems). However, irrespective of adopted institutions, the widespread extrapolation of rational prospective voting hinges on the absence of conflicting primed issues (e.g., in the context of our project, the priming of "men's issues" alongside of the priming of "women's issues"). Future research should further probe the real-world, long-lasting implications of the

\footnotetext{
${ }^{22}$ Bhalotra, Clots-Figueras, and Iyer (2017) find that the election of female state legislators in India breeds subsequent participation of Indian women in elections.

${ }^{23}$ Such research would dialogue nicely with contemporary Brazilian and Indian political studies that assess whether the presence of women in elected offices at the local level and in public administration results in the adoption of women-friendly policies (Chattopadhyay and Duflo 2004; Schwindt-Bayer 2006; Meier and Funk 2017).
} 
Zika virus and leverage the recently emergent COVID-19 pandemic to test the generalizability of rational prospective voting. ${ }^{24}$

Overall, this article probes and extends an already-saturated literature on political behavior. We discern that, even under arguably unlikely circumstances, voters eschew retrospective voting in favor of prospective voting and that haphazard, apolitical events can have important and desirable implications for electoral outcomes. As the buzz around elections takes on different forms in response to unpredictable epidemics, devastating natural disasters, and/or terrorist attacks, scholars should explore the political effects.

\section{Additional File}

The additional file for this article can be found as follows:

- Appendix. DOI: https://doi.org/10.25222/larr.916.s1

\section{Acknowledgments}

The views expressed in this paper are the authors' alone and in no way represent the opinions, standards, or policy of the United States Air Force Academy or the United States government. PA\#: USAFA-DF-2020-380.

\section{Author Information}

Kelly Senters Piazza is assistant professor of political science at the United States Air Force Academy. She received her PhD from the University of Illinois at Urbana-Champaign in August 2018. Dr. Piazza specializes in comparative politics and studies decentralization, subnational fragmentation, democratic transitions, corruption, and gender politics in Latin America. She has published on these topics in Latin American Politics and Society, the Handbook of Brazilian Politics, and the Handbook on Geographies of Corruption. The Lemann Foundation, the Tinker Foundation, and the United States Department of Education have contributed funding to her research.

Rodrigo Schneider is assistant professor of economics at Skidmore College. He received his bachelor's degree in economics from Insper in 2010; his master's degree in economics from University of Brasília in 2012; and his PhD in economics from the University of Illinois at Urbana-Champaign in 2018. Dr. Schneider specializes in public policy, political economy, applied econometrics, and development. He has published on these topics in Latin American Politics and Society, Economics of Governance, Economics Letter, and the Journal of Applied Economics.

\section{References}

Acemoglu, Daron, David H. Autor, and David Lyle. 2004. "Women, War, and Wages: The Effect of Female Labor Supply on the Wage Structure at Midcentury." Journal of Political Economy 112 (3): 497-551. DOI: https://doi.org/10.1086/383100

Achen, Christopher H., and Larry M. Bartels. 2004a. Blind Retrospection: Electoral Responses to Drought, Flu, and Shark Attacks. Madrid: Instituto Juan March de Estudios e Investigaciones.

Aiken, Abigail, Rebecca Gomperts, James Trussell, Marc Worrell, and Catherine E. Aiken. 2016. "Requests for Abortion in Latin America Related to Concern about Zika Virus Exposure." New England Journal of Medicine 275: 396-398. DOI: https://doi.org/10.1056/NEJMc1605389

Alexander, Deborah, and Kristi Andersen. 1993. "Gender as a Factor in the Attribution of Leadership Traits." Political Research Quarterly 46 (3): 527-545. DOI: https://doi.org/10.1177/106591299304600305

Anderson, Christopher J. 2007. "The End of Economic Voting? Contingency Dilemmas and the Limits of Democratic Accountability." Annual Review of Political Science 10:271-296. DOI: https://doi.org/10.1146/ annurev.polisci.10.050806.155344

Basabe-Serrano, Santiago. 2020. "La sub representación de mujeres en gabinetes ministeriales: El caso ecuatoriano en perspectiva comaprada, 1979-2015." Latin American Research Review 55 (1): 31-48. DOI: https://doi.org/10.25222/larr.204

Bauer, Nichole M. 2015. "Emotional, Sensitive, and Unfit for Office? Gender Stereotype Activation and Support Female Candidates." Political Psychology 36 (6): 691-708. DOI: https://doi.org/10.1111/pops.12186

${ }^{24}$ This research would engage Boas and Hidalgo's (2019) article in which they experimentally discern that voters who are informed about incumbent activity related to the mosquito-borne viruses use that information to inform their electoral choices. 
BBC. 2017. "Zika Virus: Brazil Says Emergency Is Over." May 12. http://www.bbc.com/news/world-latinamerica-39892479.

Bhalotra, Sonia, Irma Clots-Figueras, and Lakshmi Iyer. 2017. “Pathbreakers? Women's Electoral Success and Future Political Participation." Economic Journal 128 (613): 1944-1878. DOI: https://doi.org/10.1111/ ecoj.12492

Boas, Taylor C., and Daniel F. Hidalgo. 2019. "Electoral Incentives to Combat Mosquito-Borne Illnesses: Experimental Evidence from Brazil." World Development 113: 89-99. DOI: https:// doi.org/10.1016/j.worlddev.2018.08.013

Brollo, Fernanda, and Ugo Troiano. 2016. "What Happens When a Woman Wins an Election? Evidence from Close Races in Brazil." Journal of Development Economics 122: 28-45. DOI: https://doi.org/10.1016/j .jdeveco.2016.04.003

Chaney, Elsa M. 1979. Supermadre: Women in Politics in Latin America. Austin: University of Texas Press.

Chattopadhyay, Raghabendra, and Ester Duflo. 2004. "Women as Policy Makers: Evidence from a Randomized Policy Experiment in India." Econometrica 72 (5): 1409-1443. DOI: https://doi.org/10.1111/j.14680262.2004.00539.x

Cohen, Mollie J., and Claire Q. Evans. 2018. "Latin American Views on Abortion in the Shadow of the Zika Epidemic." LAPOP Topical Brief 033, Vanderbilt University, Nashville, TN.

Cole, Shawn, Andrew Healy, and Eric Werker. 2012. "Do Voters Demand Responsive Governments? Evidence from Indian Disaster Relief." Journal of Development Economics 97 (2): 167-181. DOI: https:// doi.org/10.1016/j.jdeveco.2011.05.005

Dolan, Kathleen. 2005. "Do Women Candidates Play to Gender Stereotypes? Do Men Candidates Play to Women? Candidate Sex and Issue Priorities on Campaign Websites." Political Research Quarterly 58 (1): 31-44. DOI: https://doi.org/10.1177/106591290505800103

Dolan, Kathleen. 2010. "The Impact of Gender Stereotyped Evaluations on Support for Women Candidates." Political Behavior 32 (1): 69-88. DOI: https://doi.org/10.1007/s11109-009-9090-4

Dolan, Kathleen. 2014. "Gender Stereotypes, Candidate Evaluations, and Voting for Women Candidates: What Really Matters?" Political Research Quarterly 67 (1): 96-107. DOI: https:// doi.org/10.1177/1065912913487949

Downs, Anthony. 1957. An Economic Theory of Democracy. New York: Harper and Row.

Eagly, Alice H., and Steven J. Karau. 2002. "Role Congruity Theory of Prejudice toward Female Leaders." Psychological Review 109 (3): 573. DOI: https://doi.org/10.1037/0033-295X.109.3.573

Escobar-Lemmon, Maria, and Michelle M. Taylor-Robinson. 2009. "Getting to the Top: Career Paths of Women in Latin American Cabinets." Political Research Quarterly 62 (4): 685-699. DOI: https:// doi.org/10.1177/1065912908322414

Exame. 2016. "Geraldo Julio (PSB): Recife, Campos e a crise." September 20. https://exame.abril.com.br/ brasil/geraldo-julio-psb-recife-campos-e-a-crise/.

Fair, C. Christine, Patrick Kuhn, Neil A. Malhotra, and Jacob Shapiro. 2017. "Natural Disasters and Political Engagement: Evidence from the 2010-11 Pakistani Floods." Stanford University Graduate School of Business Research Paper No. 17-42. SSRN.

Fiorina, Morris P. 1981. Retrospective Voting in American National Elections. New Haven, CT: Yale University Press.

Franceschet, Susan, and Jennifer M. Piscopo. 2008. "Gender Quotas and Women's Substantive Representation: Lessons from Argentina." Politics and Gender 4 (3): 393-425. DOI: https://doi.org/10.1017/ S1743923X08000342

Fuchs, Alan, and Lourdes Rodriguez-Chamussy. 2014. "Voter Response to Natural Disaster Aid: QuasiExperimental Evidence from Drought Relief Payments in Mexico." Policy Research Working Paper No. 6836. World Bank, Washington, DC. DOI: https://doi.org/10.1596/1813-9450-6836

Funk, Kendall D., Magda Hinojosa, and Jennifer M. Piscopo. 2017. "Still Left Behind: Gender, Political Parties, and Latin America's Pink Tide." Social Politics: International Studies in Gender, State and Society 24 (4): 399-424. DOI: https://doi.org/10.1093/sp/jxx012

Funk, Kendall D., Magda Hinojosa, and Jennifer M. Piscopo. 2019. "Women to the Rescue: The Gendered Effects of Public Discontent on Legislative Nominations in Latin America." Party Politics, first published June 21, 2019. DOI: https://doi.org/10.1177/1354068819856614

Gasper, John T., and Andrew Reeves. 2011. "Make It Rain? Retrospection and the Attentive Electorate in the Context of Natural Disasters." American Journal of Political Science 55 (2): 340-355. DOI: https:// doi.org/10.1111/j.1540-5907.2010.00503.x 
Hayes, Danny. 2011. "When Gender and Party Collide: Stereotyping in Candidate Trait Attribution." Politics and Gender 7 (2): 133-165. DOI: https://doi.org/10.1017/S1743923X11000055

Healy, Andrew, and Neil Malhotra. 2013. "Retrospective Voting Reconsidered." Annual Review of Political Science 16: 285-306. DOI: https://doi.org/10.1146/annurev-polisci-032211-212920

Healy, Andrew, Neil Malhotra, and Cecilia Hyunjung Mo. 2010. "Irrelevant Events Affect Voters' Evaluations of Government Performance." Proceedings of the National Academy of Sciences 107 (29): 12804-12809. DOI: https://doi.org/10.1073/pnas.1007420107

Herriman, Robert. 2016. "Brazil Reports 1.2 Million Dengue Cases in First Four Months of 2016." Outbreak News Today, May 29. http://outbreaknewstoday.com/brazil-reports-1-2-million-dengue-cases-in-firstfour-months-of-2016/.

Herrnson, Paul S., J. Celeste Lay, and Atiya K. Stokes. 2003. “Women Running as Women': Candidate Gender, Campaign Issues, and Voter-Targeting Strategies." Journal of Politics 65 (1): 244-255. DOI: https:// doi.org/10.1111/1468-2508.t01-1-00013

Hinojosa, Magda, Jill Carle, and Gina Serignese Woodall. 2018. "Speaking as a Woman: Descriptive Presentation and Representation in Costa Rica's Legislative Assembly." Journal of Women, Politics, and Policy 39 (4): 407-429. DOI: https://doi.org/10.1080/1554477X.2018.1506204

Htun, Mala. 2002. "Puzzles of Women's Rights in Brazil." Social Research 69 (3): 733-751.

Huddy, Leonie, and Nayda Terkildsen. 1993. "Gender Stereotypes and the Perception of Male and Female Candidates." American Journal of Political Science 37 (1): 119-147. DOI: https://doi.org/10.2307/2111526

Key, V. O. 1966. The Responsible Electorate: Rationality in Presidential Voting, 1936-1960. Cambridge, MA: Harvard University Press. DOI: https://doi.org/10.4159/harvard.9780674497764

Kittilson, Miki Caul, and Kim Fridkin. 2008. "Gender, Candidate Portrayals and Election Campaigns: A Comparative Perspective." Politics and Gender 4 (3): 371-392. DOI: https://doi.org/10.1017/ S1743923X08000330

Lawless,JenniferL.2004. “Women,War,andWinningElections:GenderStereotypinginthepost-September 11th Era." Political Research Quarterly 57 (3): 479-490. DOI: https://doi.org/10.1177/106591290405700312

Leeper, Mark Stephen. 1991. "The Impact of Prejudice on Female Candidates: An Experimental Look at Voter Inference." American Politics Quarterly 19 (2): 248-261. DOI: https:// doi.org/10.1177/1532673X9101900206

Lloren, Anouk, Jan Rosset, and Reto Wüest. 2015. "Descriptive and Substantive Representation of Poor Citizens in Switzerland." Swiss Political Science Review 21 (2): 254-260. DOI: https://doi.org/10.1111/ spsr.12159

Mainwaring, Scott. 1999. Rethinking Party Systems in the Third Wave of Democratization: The Case of Brazil. Stanford, CA: Stanford University Press.

McDermott, Monika L. 1997. "Voting Cues in Low-Information Elections: Candidate Gender as a Social Information Variable in Contemporary United States Elections." American Journal of Political Science 41 (1): 270-283. DOI: https://doi.org/10.2307/2111716

Meier, Kenneth J., and Kendall D. Funk. 2017. "Women and Public Administration in a Comparative Perspective: The Case of Representation in Brazilian Local Governments." Administration and Society 49 (1): 121-142. DOI: https://doi.org/10.1177/0095399715626201

Miller, Michael K. 2013. "For the Win! The Effect of Professional Sports Records on Mayoral Elections." Social Science Quarterly 94 (1): 59-78. DOI: https://doi.org/10.1111/j.1540-6237.2012.00898.x

Morgan, Jana. 2015. "Gender and the Latin American Voter." In The Latin American Voter, edited by Ryan Carlin, Matthew Singer, and Elizabeth Zechmeister, 143-167. Ann Arbor: University of Michigan Press.

Morgan, Jana, and Melissa Buice. 2013. "Latin American Attitudes toward Women in Politics: The Influence of Elite Cues, Female Advancement, and Individual Characteristics." American Political Science Review 107 (4): 644-662. DOI: https://doi.org/10.1017/S0003055413000385

o Globo. 2016. 'Aedes,' o mosquito que sumiu do debate na campanha eleitoral: Especialistas lamentam que candidatos não tenham propostas contra epidemias." September 12, 2016. https://oglobo.globo.com/ brasil/aedes-mosquito-que-sumiu-do-debate-na-campanha-eleitoral-20091754.

Power, Timothy J., and Rodrigo Rodrigues-Silveira. 2019. "Mapping Ideological Preferences in Brazilian Elections, 1994-2018: A Municipal-Level Study." Brazilian Political Science Review 13 (1): 1-27. DOI: https://doi.org/10.1590/1981-3821201900010001

Romero, Simon, and Anna Jean Kaiser. 2016. "Some See Anti-Women Backlash in Ouster of Brazil's President." New York Times, September 7. https://www.nytimes.com/2016/09/08/world/mericas/some-see-antiwomen-backlash-in-ouster-of-brazils-president.html. 
Sacchet, Teresa. 2018. “Why Gender Quotas Don't Work in Brazil? The Role of the Electoral System and Political Finance." Colombia International 95: 25-54. DOI: https://doi.org/10.7440/colombiaint95.2018.02

Samuels, David. 2001. Money, Elections, and Democracy in Brazil. Cambridge: Cambridge University Press. DOI: https://doi.org/10.2307/3176970

Sanbonmatsu, Kira. 2002. "Gender Stereotypes and Vote Choice." American Journal of Political Science 46 (1): 20-34. DOI: https://doi.org/10.2307/3088412

Schwindt-Bayer, Leslie A. 2006. "Still Supermadres? Gender and the Policy Priorities of Latin American Legislators." American Journal of Political Science 50 (3): 570-585. DOI: https://doi.org/10.1111/j.15405907.2006.00202.x

Schwindt-Bayer, Leslie A. 2010. Political Power and Women's Representation in Latin America. Oxford: Oxford University Press. DOI: https://doi.org/10.1093/acprof:oso/9780199731954.001.0001

Senters, Kelly, and Rodrigo Schneider. 2019. "The Buzz on Babies: The Fertility-Depressing Effect of the Zika Virus in Brazil." Brazilian Journal of Policy and Development 1 (1). DOI: https://doi.org/10.52367/ BRJPD.2675-102X.2019.1.1.45-60

Setzler, Mark. 2019. "Adversity, Gender Stereotyping, and Appraisals of Female Political Leadership: Evidence from Latin America." Latin Americanist 62 (2): 189-219.

Shafer, Karen. 2018. "Political Ambition." Oxford Bibliographies. https://www.oxfordbibliographies.com/ view/document/obo-9780199756223/obo-9780199756223-0238.xml. DOI: https://doi.org/10.1093/ obo/9780199756223-0238

Sinclair, Betsy, Thad E. Hall, and Michael Alvarez. 2011. "Flooding the Vote: Hurricane Katrina and Voter Participation in New Orleans." American Politics Research 39 (5): 921-957. DOI: https:// doi.org/10.1177/1532673X10386709

Speck, Bruno Wilhelm. 2018. "O efeito contagiante do successo feminine: A eleição de prefeitas e o impacto sobre as candidaturas nos próximos pleitos." Latin American Research Review 53 (1): 57-55. DOI: https:// doi.org/10.25222/larr.398

Steenbergen, Marco R., and Céline Colombo. 2018. "Heuristics in Political Behavior." In The Oxford Handbook of Behavioral Political Science, edited by Alex Mintz and Lesley Terris, 1-28 Oxford: Oxford University Press. DOI: https://doi.org/10.1093/oxfordhb/9780190634131.013.9

Veja. 2016. "Janot defende liberação do aborto para grávidas com zika." September 8, 2016. https://veja .abril.com.br/politica/janot-defende-liberacao-do-aborto-para-gravidas-com-zika/.

Wampler, Brian. 2004. "Exploring Accountability Through Participatory Institutions: Mayors, Citizens, and Budgeting in Three Brazilian Municipalities." Latin American Politics and Society 46 (20): 73-99. DOI: https://doi.org/10.1111/j.1548-2456.2004.tb00276.x

Wylie, Kristin N. 2018. Party Institutionalization and Women's Representation in Democratic Brazil. Cambridge: Cambridge University Press. DOI: https://doi.org/10.1017/9781108612722

How to cite this article: Piazza, Kelly Senters, and Rodrigo Schneider. 2021. The Electoral Buzz: Rational Prospective Voting and the Politics of the Zika Epidemic in Brazil. Latin American Research Review 56(3), pp. 575-591. DOl: https://doi.org/10.25222/larr.916

Submitted: 03 April 2019

Accepted: 13 February 2020

Published: 07 September 2021

Copyright: $\odot 2021$ The Author(s). This is an open-access article distributed under the terms of the Creative Commons Attribution 4.0 International License (CC-BY 4.0), which permits unrestricted use, distribution, and reproduction in any medium, provided the original author and source are credited. See http://creativecommons.org/ licenses/by/4.0\%. 